\author{
RENATA ŚLIWA \\ Uniwersytet Pedagogiczny w Krakowie, Polska • Pedagogical University of Cracow, Poland \\ Piotr WaląG, Sylwester Tabor \\ Uniwersytet Rolniczy w Krakowie, Polska • University of Agriculture in Cracow, Poland
}

\title{
Ewolucja struktur produkcii i zatrudnienia w gospodarkach rynkowych. Wnioski dla Polski
}

\section{Evolution of the Production and Employment Structures in Market Economies. Implications for Poland}

\begin{abstract}
Streszczenie: Artykuł oddaje zróżnicowaną problematykę przemian strukturalnych w gospodarkach rynkowych krajów wysoko rozwiniętych, które przeszły silną industrializację, oraz w gospodarkach rynkowych krajów rozwijających się, które przedwcześnie wchodzą w dezindustrializację. Ukazanie w warstwie poznawczej opracowania najistotniejszych kwestii przemian strukturalnych pozwala - w jego warstwie empirycznej podjąć próbę zarysowania możliwych interpretacji dotyczących efektów zmian struktury zatrudnienia w badanych krajach.Za pomocą sześciosektorowego podziału gospodarki przedstawiono zmiany udziałów zatrudnienia w wybranych gospodarkach wlatach 1970-2014. Przy użyciu prostych współczynników statystycznych zobrazowano korelację między udziałami zatrudnienia w przemyśle przetwórczym i usługach rynkowych a poziomami PKB per capita oraz określono współczynniki determinacji.Zasadniczym celem pracy jest wyeksponowanie przedwczesnej dezindustrializacji gospodarki Polski i wskazanie potrzeby jej reindustrializacji.

Abstract: The paper presents the diversified problems of structural changes in market economies of highly developed countries which have undergone heavy industrialization and in market economies of yet developing countries and then experience premature deindustrialization. The cognitive layer of the article constitutes the basis for the attempt at interpreting the effects of employment structure changes in the empirical layer. The six-sector division of economy serves to explore the changes of employment in selected countries for the period of 1970-2014. The application of simple statistical tools discloses the relation between the structure of employment in manufacturing and market services, and the level of GDP per capita. The main emphasis however, is put on highlighting premature deindustrialization in Poland, and the need for reindustrialization in this type of market economies.
\end{abstract}

Słowa kluczowe: dezindustrializacja; dualizm dezindustrializacji; przemiany strukturalne; reindustrializacja

Keywords: deindustrialization; dualism of deindustrialization; reindustrialization; structural change

Otrzymano: 24 stycznia 2016

Received: 24 January 2016

Zaakceptowano: 23 lipca 2016

Accepted: 23 July 2016

\section{Sugerowana cytacja / Suggested citation:}

Śliwa, R., Waląg, P., Tabor, S. (2016). Ewolucja struktur produkcji i zatrudnienia w gospodarkach rynkowych. Wnioski dla Polski. Prace Komisji Geografii Przemysłu Polskiego Towarzystwa Geograficznego, 30(3), 45-58. 


\section{WSTĘP}

Dokonujące się przemiany fundamentalnych praw i mechanizmów ekonomicznych, sprowadzane niejednokrotnie do zjawiska konstytuowania się nowego paradygmatu rozwoju gospodarczego, mają swoje początki $w$ naturalnych uwarunkowaniach związanych ze strukturalnymi zmianami gospodarek rynkowych, rozumianymi jako zmiany struktury produkcji i zatrudnienia. U podstaw mechanizmu przemian strukturalnych leżą postęp techniczny i zmiany struktury spożycia wśród ludności, nieodłącznie związane $\mathrm{z}$ istotą funkcjonowania gospodarki rynkowej. Jednolitość tych zmian, ujawniająca się jedynie w długich okresach badawczych, nie pozbawia ich głębokiej specyfiki, kryjącej się za poszczególnymi uwarunkowaniami krajowymi. Zróżnicowanie procesów przemian strukturalnych najwyraźniej przejawia się w grupie krajów wysoko rozwiniętych i rozwijających się. Naturalne zmiany w krajach najwcześniej się industrializujących, w których dotychczas panował dobrobyt, prowadzące do wzrostu produkcji i zatrudnienia w sektorze usług kosztem ich udziałów w sektorze przemysłowym, nie powinny skłaniać krajów rozwijających się do „przeskakiwania” etapów industrializowania gospodarki w warunkach konkurencji rynkowej i wzmacniania zjawiska dezindustrializacji.

Przedmiotem niniejszych rozważań są zmiany strukturalne w gospodarkach, które doświadczyły silnej industrializacji w warunkach rynkowych, oraz w tych, które nie przechodziły tego typu industrializacji, a odnotowują już symptomy dezindustrializacji.

Celem opracowania jest ukazanie Polski jako gospodarki, która - wzmacniając zachodzące już procesy przedwczesnej dezindustrializacji - ryzykuje zamknięcie ważnych kanałów prowzrostowych (uwięzienie siły roboczej w rolnictwie i niskoprodukcyjnych działach usług rynkowych czy produkcji sfery nieformalnej).

Praca ta składa się z czterech zasadniczych części. W dwóch pierwszych zaprezentowano - na podstawie literatury przedmiotu - wyniki badań odnoszących się do przemian strukturalnych, które miały miejsce w gospodarkach wysoko rozwiniętych i rozwijających się. W części analitycznej przedstawiono alternatywny podział gospodarki na sektory, który wyraźniej oddaje obraz zmian strukturalnych. Zastosowano go do analizy wybranych gospodarek. Ujęto w nim również zarys możliwych relacji między udziałami zatrudnienia $\mathrm{w}$ przetwórstwie przemysłowym i usługach rynkowych a poziomem PKB per capita dla wybranych krajów. W części czwartej przedstawiono ważniejsze wnioski dla Polski.

\section{CZYNNIKI PRZEWAŻAJĄCE ${ }^{1}$ I PRZEMIANY STRUKTURY GOSPODAREK RYNKOWYCH W KRAJACH WYSOKO ROZWINIĘTYCH}

Skala zmian udziałów poszczególnych sektorów w rozwoju wysoko rozwiniętych gospodarek napędzana była wyraźnie dwoma czynnikami, które uznano za wspólne dla wielu złożonych zjawisk oraz których skumulowane efekty oddziaływania były wyraźnie obserwowalne w czasie, mimo działania innych zmiennych. Postęp technologiczny (mierzony wydajnością) oraz zmiany struktury spożycia wymieniane są jako

${ }^{1} \mathrm{~J}$. Fourastié proponuje poszukiwanie w ekonomii zdarzeń autonomicznych i zjawisk przeważających. Zjawiska przeważające mają dwie podstawowe cechy. Po pierwsze, są one wspólne dla dużej liczby zjawisk 
determinanty przemian strukturalnych gospodarek rynkowych (Fisher, 1945; Fourastié, 1954; Clark, 1957; Fourastié, 1972; Kwiatkowski, 1980).

Wzrosty wydajności w rolnictwie powodowały przyrost wielkości produkcji żywnościowej. Jednocześnie wzrastał poziom dochodów per capita, który wywoływał zmiany w strukturze spożycia. W miarę wzrostu dochodów następował spadek udziału żywności w wydatkach ogółem. Przesuwało się też zapotrzebowanie ludności z produktów rolniczych do produktów przemysłowych, a następnie usług. Rosnący popyt na produkty przemysłowe podnosił poziom produkcji w sektorze przemysłowym, głównie w przetwórstwie. Początkowo, przy niskiej wydajności, wzrost ten dokonywał się głównie poprzez przyrost zatrudnienia. W ten sposób sektor przemysłu absorbował siłę roboczą odchodzącą z rolnictwa. Proces ten był tym bardziej widoczny, im większa była różnica między tempem wzrostu wydajności (początkowo powolnym) a tempem wzrostu popytu w sektorze przemysłowym. Zwiększenie wydajności w przemyśle poprzez wprowadzenie wynalazków pierwszej i drugiej rewolucji przemysłowej zmniejszyło różnicę między możliwą do uzyskania wielkością produkcji a popytem. Gdy wielkość produkcji napędzana coraz większą wydajnością przekroczyła poziom zapotrzebowania na produkty przemysłowe, zatrudnienie zaczęło spadać. Podobnie jak w końcowym okresie ery agrarnej, tak już w fazie największego tempa rozwoju industrializacji duży wzrost wydajności i produkcji powodował coraz większy wzrost dochodów (Fisher, 1952: 828).

N. Kaldor, na gruncie materiału empirycznego dostarczonego przez S. Kuznetsa, H. Chenery'ego i R. Syrquina, wskazywał na wagę analizy wzrostu gospodarczego na podstawie przemian strukturalnych w rolnictwie, przemyśle i usługach oraz ich wzajemnych relacji. Dowodził on, że przemysł (obok rolnictwa) w największym stopniu przyczyniał się do pobudzania wzrostu. W przemyśle bowiem, w związku z absorpcją postępu technicznego, rejestrowany jest stosunkowo wysoki wzrost wydajności (Kaldor, 1967). Dzięki ujawniającym się silnie w przemyśle efektom skali i rozproszenia, podatności na handel międzynarodowy (Dasgupta, Singh, 2005), a także wchłanianiu zasobów słabo wykwalifikowanej siły roboczej (Rodrik, 2016: 19-20) zwiększanie udziałów przemysłu niesie ze sobą duże możliwości prowzrostowe. Zaawansowanie technologiczne stanowiło o wzrostach produktywności w przemyśle oraz w przeważającej mierze o spadkach zatrudnienia w tym sektorze (Rodrik, 2016: 4, 27).

W industrializacji procesy gospodarowania zostały zdominowane przez regułę sprawności. Większa wydajność maszyn, wprowadzenie zasad „naukowego zarządzania", lepsze wykorzystanie czasu pracy - miało to wpłynąć na zwiększenie produkcji i zysków oraz na dobrobyt. Zmiany te wyraźnie wskazywały, że powstający system doprowadzi do niemal „nieograniczonych możliwości produkcyjnych” i wypierania siły roboczej (bezrobocia technologicznego) (Rifkin, 2001: 73, 112). Wzrost dochodów generował dalsze zmiany w strukturze popytu - od produktów podstawowych do produktów wyższego rzędu (Fisher, 1952: 828). Zmieniało to strukturę wydatków,

złożonych. Po drugie, kumulują się, co oznacza, że powodują skutki, które narastają, mimo zmiennych okoliczności w czasie i miejscu. Należy jednak pamiętać, że w naukach społecznych czas nie jest jednorodny - wtedy zjawiska przeważające nie będą stałe w czasie. Oznacza to, że gdy występują w bardzo długim okresie (100 lat np. w ekonomii), są słabo uchwytne w średnim okresie (pięciu lat) i nieznaczące w krótkim okresie (sześć miesięcy), przy czym ich nasilenie będzie zależeć od tempa zmian warunków gospodarczych (Fourastié, 1972: 192). 
w której spadała ilość dóbr przemysłowych, a rosła ilość usług. Ten coraz większy popyt na usługi, przy stosunkowo małej lub nierosnącej wydajności w tym sektorze, powodował, że była tam absorbowana cała siła robocza wypierana z przemysłu w okresie dezindustrializacji. W sektorze usług to przede wszystkim zatrudnienie warunkuje wielkość produkcji. W związku z ciągle rosnącym, praktycznie nieograniczonym popytem na usługi oraz dość niskim poziomem wydajności (z niskim tempem wzrostu), sektor usług przez cały czas przejmuje siłę roboczą z rolnictwa i przemysłu.

Obserwacja procesów wzrostowych w wielu krajach rozwiniętych (uprzemysłowionych i z silnymi przewagami komparatywnymi) i rozwijających się (np. Indie) nakazuje co najmniej ostrożnie podchodzić do dotychczasowych wniosków na temat roli sektora usług we wzroście wydajności w całej gospodarce. Wskazuje się, że takie usługi, jak: usługi technologii informacyjnych, finansowe, handel detaliczny, telekomunikacja, usługi biznesowe, transport wywołują silne efekty rozproszenia w gospodarce, tworzą nowe produkty i procesy, mają często wpływ na handel (Dasgupta, Singh, 2005: 28) i w ten sposób mogą mieć swój istotny udział w zwiększeniu wydajności. Z drugiej strony wzrost poziomu niektórych usług wydaje się zależeć od skali rozwoju przetwórstwa przemysłowego (Dasgupta, Singh, 2005). Jednak duża heterogeniczność sektora usług sprawia, że jego analizy, prowadzone na wysokim poziomie zagregowania, są mało użyteczne w dostarczaniu wiedzy na temat istoty usług (Piketty, 2015: 116) i ich udziału w zmianach wydajności poszczególnych gospodarek.

\section{PRZEMIANY STRUKTURALNE W KRAJACH ROZWIJAJĄCYCH SIĘ}

Wiele gospodarek krajów rozwijających się rejestruje szybszy wzrost produkcji sektora usług niż sektora przetwórstwa przemysłowego. Zjawisko to, nazywane w literaturze dezindustrializacją, ujawnia się również na stosunkowo niskich poziomach PKB per capita i towarzyszy mu często przy znacznych przyrostach PKB. Obserwowany jest wówczas bezzatrudnieniowy wzrost gospodarczy (Dasgupta, Singh, 2005).

Historyczny punkt zwrotny przejścia gospodarek wysoko rozwiniętych z dominacji produkcji przemysłowej na produkcję usług nastąpił na poziomie prawie 10 tys. dol. w cenach bieżących. Obecnie szacuje się, że w niektórych krajach (rozwijających się) zachodzi on już na poziomie 3 tys. dol. Wobec tych faktów problematyczna staje się ocena owej zmiany. Nie jest bowiem jednoznaczne, czy ten typ przedwczesnej dezindustrializacji, kiedy gospodarka nie osiągnęła jeszcze odpowiedniego poziomu rozwoju przemysłowego, jest szkodliwy, czy korzystny dla długookresowego rozwoju kraju.

Należy podkreślić, że możliwe jest, by gospodarka przechodziła dezindustrializację w kategoriach zatrudnienia, a jednocześnie nie następowała jeszcze dezindustrializacja w kategoriach produkcji. Taki dualizm przebiegu tego procesu jest możliwy przy spotykanym bardzo często $w$ krajach rozwijających się zjawisku bezzatrudnieniowego wzrostu gospodarczego (powodowanym szybkim wzrostem produktywności w przemyśle - procesami delokalizacji „dojrzałych przemysłów” i konwergencji - oraz jeszcze nienasyconym popytem na dobra przemysłowe). Dezindustrializacja w ujęciu zmian produkcji i zmian zatrudnienia nie jest negatywna, jeśli wynika z naturalnej reakcji na 
zmianę gustów i technologii. Może jednak budzić niepokój, jeżeli pojawia się na niskich poziomach dochodów per capita. Dezindustrializacja w kategoriach produkcji i zatrudnienia (pozostawanie ich w niezmienionym stanie lub ich spadające udziały) mogłaby wskazywać na nadmiar siły roboczej w rolnictwie, która albo pozostanie w tym sektorze, albo zostanie przesunięta do niskoprodukcyjnych manufaktur w sektorze nieformalnym i nieformalnych usług (Dasgupta, Singh, 2006: 5-6).

D. Rodrik (2016) wskazuje, że bez właściwie przebytej industrializacji kraje rozwijające się stają wobec „przedwczesnej dezindustrializacji”, która pociąga za sobą negatywne skutki dla rozwoju gospodarczego, takie jak spadek wydajności w gospodarce, a za tym - spadek dochodu i poziomu dobrobytu ludności, niewielką absorpcję niewykwalifikowanej siły roboczej, osłabienie możliwości eksportowych. 0 ile w krajach wysoko rozwiniętych przemiany strukturalne, w tym dezindustrializacja, warunkowane były głównie postępem technologicznym, o tyle w krajach rozwijających się dezindustrializacja wynika głównie z liberalizacji handlu i jest postrzegana jako skutek globalizacji oraz nasilonego handlu międzynarodowego ${ }^{2}$.

Szczególnie niekorzystna sytuacja występuje w tych krajach rozwijających się, które nie mają wykształconych silnych przewag komparatywnych. W takich warunkach państwa te nie tylko stają się importerami netto dóbr przetwórstwa przemysłowego, lecz także zostają wystawione na niekorzystne dla nich zmiany cen relatywnych. Presja, aby obniżać ceny towarów przemysłu przetwórczego w krajach na wysokim poziomie postępu technologicznego, rozprzestrzenia się poprzez handel również na kraje importujące te dobra. W efekcie państwa te rejestrują spadki udziałów przetwórstwa przemysłowego w zatrudnieniu i produkcji. W zależności od tego, jak bardzo kraje rozwijające się mają umocowane swoje przewagi komparatywne w produkcji dóbr przetwórstwa przemysłowego, tak istotnie salda zmian wpływu technologii i handlu będą obniżać udziały produkcji i zatrudnienia w ich przemyśle. Większy wpływ zaawansowanej technologii będzie w tych krajach podnosił udziały produkcji i zatrudnienia w przemyśle, natomiast większy wpływ handlu zagranicznego będzie te udziały odpowiednio obniżał (Rodrik, 2016).

\section{ANALIZA PRZEMIAN STRUKTURALNYCH W WYBRANYCH GOSPODARKACH}

Klasyczny podział gospodarki na trzy sektory (rolnictwo, przemysł, usługi) nie przynosi już takich korzyści płynących z kryterium podziału gospodarki, jakim są różnice w stopach wzrostu wydajności pracy oraz zmiany struktury spożycia. Proponuje się modyfikację tego podziału ze względu na kryterium, jakim jest zmiana struktury spożycia i zróżnicowanie stóp wzrostu produktywności w sektorach. Bazując na klasyfikacji PKD, wydzielono sześć sektorów gospodarki:

Sektor I: rolnictwo, łowiectwo, leśnictwo, rybactwo.

Sektor II: przemysł - górnictwo, wytwarzanie i zaopatrywanie w energię elektryczną, gaz, wodę.

Sektor III: przemysł - przetwórstwo przemysłowe.

Sektor IV: budownictwo (usługi budowlane).

\footnotetext{
${ }^{2}$ Takie wnioski wypływały już np. z pracy Rowthorn, Ramaswamy (1997: 35-36).
} 
Sektor V: usługi rynkowe - handel i naprawy, hotele i restauracje, transport, gospodarka magazynowa i łączność, pośrednictwo finansowe, obsługa nieruchomości i firm.

Sektor VI: usługi nierynkowe (osobowe) - administracja publiczna i obrona narodowa; obowiązkowe ubezpieczenia społeczne i zdrowotne, edukacja, ochrona zdrowia i pomoc społeczna, działalność usługowa, komunalna, społeczna i indywidualna, pozostała.

Przyjęcie takiego podziału struktury gospodarek będzie mocniej eksplorować korzyści z przyjętego kryterium (Waląg, 2012).

Poniższa tabela przedstawia ewolucję struktury w podziale na sześć sektorów wybranych gospodarek rynkowych w latach 1970-2014.

Tab. 1. Struktura wybranych gospodarek rynkowych w latach 1970-2014, udziały poszczególnych sektorów w zatrudnieniu ogółem

\begin{tabular}{|c|c|c|c|c|c|c|c|c|c|c|c|c|}
\hline Lata & م̊ & $\begin{array}{l}\stackrel{\infty}{\infty} \\
\stackrel{్}{\sim}\end{array}$ & ஓे & $\begin{array}{l}\stackrel{2}{\sigma} \\
\stackrel{\sim}{\sim}\end{array}$ & ○ & $\stackrel{\text { 농 }}{\stackrel{ }{N}}$ & : & 웅 & $\underset{\sim}{\stackrel{-}{N}}$ & 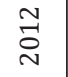 & $\stackrel{m}{\stackrel{m}{\sim}}$ & 㐫 \\
\hline \multicolumn{13}{|l|}{ Polska } \\
\hline Rolnictwo & - & - & - & 22,6 & 18,8 & 17,4 & 13,3 & 12,8 & 12,7 & 12,6 & 12 & 11,5 \\
\hline Przemysł & - & - & - & 32 & 30,8 & 29,2 & 31,1 & 30,1 & 30,6 & 30,4 & 30,5 & 30,5 \\
\hline \multicolumn{2}{|l|}{$\begin{array}{l}\text { w tym, przetwórstwo } \\
\text { przemysłowe }\end{array}$} & & & 21,1 & 20 & 20 & 19,3 & 18,5 & 18,7 & 18,6 & 19,1 & 19,1 \\
\hline \multicolumn{4}{|c|}{$\begin{array}{l}\text { w tym, górnictwo, wytwarzanie } \\
\text { i zaopatrywanie w energię elektryczną, } \\
\text { gaz, wodę }\end{array}$} & 4,8 & 3,8 & 3,2 & 3,6 & 3,6 & 3,7 & 3,8 & 3,8 & 3,9 \\
\hline Budownictwo & - & - & - & 6,1 & 7 & 6 & 8,2 & 8 & 8,2 & 8 & 7,6 & 7,5 \\
\hline Usługi rynkowe & - & - & - & 23,6 & 28,1 & 30,1 & 33,2 & 33,8 & 33,8 & 34,2 & 34 & 34,6 \\
\hline Usługi nierynkowe & - & - & - & 21,7 & 22,2 & 23,3 & 22,4 & 23,1 & 23 & 22,7 & 23,4 & 23,3 \\
\hline \multicolumn{13}{|l|}{ Niemcy } \\
\hline Rolnictwo & 8,6 & 5,3 & 3,5 & 3,2 & 2,6 & 2,4 & 1,7 & 1,6 & 1,6 & 1,6 & 1,4 & 1,4 \\
\hline Przemysł & b.d. & 43,7 & 39,8 & 36,5 & 33,7 & 30 & 29 & 28,5 & 28,4 & 28,3 & 28 & 28,2 \\
\hline $\begin{array}{l}\text { w tym, przetwórstwo } \\
\text { przemysłowe }\end{array}$ & 49,3 & 34 & 31,6 & 25,4 & 23,9 & 22,2 & 20,5 & 20,1 & 19,9 & 19,8 & 19,4 & 19,7 \\
\hline \multicolumn{2}{|c|}{$\begin{array}{l}\text { w tym, górnictwo, } \\
\text { wytwarzanie } \\
\text { i zaopatrywanie w energię } \\
\text { elektryczną, gaz, wodę }\end{array}$} & 1,7 & 1,6 & 1,8 & 1,2 & 1,2 & 1,8 & 1,7 & 1,8 & 1,8 & 1,8 & 1,6 \\
\hline Budownictwo & b.d. & 8 & 6,6 & 9,3 & 8,6 & 6,6 & 6,7 & 6,7 & 6,7 & 6,7 & 6,8 & 6,9 \\
\hline Usługi rynkowe & b.d. & 27,1 & 30,8 & 33,1 & 35 & 36,9 & 44 & 44,6 & 44,6 & 44,5 & 45,1 & 44,6 \\
\hline Usługi nierynkowe & b.d. & 23,9 & 25,8 & 27,2 & 28,7 & 30,7 & 24,8 & 25,2 & 25,3 & 25,5 & 25,5 & 25,7 \\
\hline \multicolumn{13}{|l|}{ Wielka Brytania } \\
\hline Rolnictwo & 3,2 & 2,6 & 2,1 & 2,06 & 1,5 & 1 & 1 & 1,2 & 1,2 & 1,2 & 1 & 1,3 \\
\hline Przemysł & 44,8 & 37,6 & 32,3 & 27,3 & 25,2 & 22,8 & 19,5 & 19,1 & 19,1 & 19,1 & 18,7 & 18,8 \\
\hline $\begin{array}{l}\text { w tym, przetwórstwo } \\
\text { przemysłowe }\end{array}$ & 34,7 & 28,3 & 22,1 & 19 & 17 & 12,7 & 9,6 & 9,9 & 9,8 & 9,9 & 9,6 & 9,8 \\
\hline
\end{tabular}




\begin{tabular}{|c|c|c|c|c|c|c|c|c|c|c|c|c|}
\hline $\begin{array}{l}\text { w tym, górnictwo, } \\
\text { wytwarzanie } \\
\text { i zaopatrywanie } \\
\text { w energię elektryczną, } \\
\text { gaz, wodę }\end{array}$ & 3,3 & 2,8 & 2,2 & 1,26 & 1,1 & 1,5 & 1,6 & 1,6 & 1,8 & 1,8 & 1,9 & 1,7 \\
\hline Budownictwo & 6,8 & 6,5 & 8 & 7,04 & 7,1 & 8,6 & 8,3 & 7,6 & 7,5 & 7,4 & 7,2 & 7,3 \\
\hline Usługi rynkowe & 28,1 & 32,9 & 38 & 40,4 & 42 & 48,3 & 49 & 48,6 & 48,8 & 49,4 & 49,3 & 49,3 \\
\hline Usługi nierynkowe & 23,8 & 26,8 & 27,1 & 29,8 & 31 & 27,7 & 29,5 & 30,3 & 30,2 & 29,4 & 29,9 & 29,7 \\
\hline \multicolumn{13}{|l|}{ Stany Zjednoczone } \\
\hline Rolnictwo & 4,5 & 3,5 & 2,8 & 2,9 & $2,6 / 1,7$ & 1,5 & 1,5 & 1,5 & 1,6 & 1,5 & 1,4 & 1,5 \\
\hline Przemysł & 34,3 & 30,5 & 26,2 & 24 & $23 / 15,6$ & 12,8 & 11,6 & 11,7 & 11,9 & 12 & 12,1 & 12,1 \\
\hline $\begin{array}{l}\text { w tym, przetwórstwo } \\
\text { przemysłowe }\end{array}$ & 26,4 & 22,1 & 18 & 16,4 & $14,8 / 14,1$ & 11,3 & 10 & 9,9 & 10,1 & 10,1 & 10,2 & 10,2 \\
\hline $\begin{array}{l}\text { w tym, górnictwo, } \\
\text { wytwarzanie } \\
\text { i zaopatrywanie } \\
\text { w energię elektryczną, } \\
\text { gaz, wodę }\end{array}$ & 1,8 & 2,2 & 1,7 & 1,5 & $1,2 / 1,5$ & 1,5 & 1,6 & 1,8 & 1,8 & 1,9 & 1,9 & 1,9 \\
\hline Budownictwo & 6,1 & 6,2 & 6,5 & 6,1 & $7 / 7,1$ & 7,8 & 6,8 & 6,4 & 6,3 & 6,2 & 6,3 & 6,6 \\
\hline Usługi rynkowe & 33,1 & 35,5 & 39 & 38,4 & $39,7 / 44,1$ & 44,7 & 44,2 & 44,2 & 44,5 & 44,7 & 44,7 & 44,7 \\
\hline Usługi nierynkowe & 28 & 30,3 & 32 & 35 & $34,7 / 31,3$ & 33,1 & 35,8 & 36,1 & 35,6 & 35,6 & 35,4 & 35 \\
\hline
\end{tabular}

Źródło: OECD (2016a); Stany Zjednoczone: do 2000 roku metodyka OECD, od 2000 roku domestic concept

Tabela 1 obrazuje zmiany struktury zatrudnienia wybranych wysoko rozwiniętych gospodarek rynkowych oraz Polski. W latach 1970-1980 po raz pierwszy zaobserwowano procesy dezindustrializacji w najbardziej rozwiniętych gospodarkach, tj. Stanów Zjednoczonych, Wielkiej Brytani i Niemiec. Procesy te dodatkowo wzmocniła prowadzona w latach sześćdziesiątych XX wieku popytowa polityka wobec przemysłu, co niewątpliwie przyczyniło się do kryzysu lat siedemdziesiątych, potęgowanego wzrostem cen surowców i stagnacją. Liberalizacja światowego handlu zapoczątkowana w latach siedemdziesiątych XX wieku, przyspieszyła procesy dezindustrializacji poprzez delokalizację produkcji dojrzałych przemysłów z krajów wysoko rozwiniętych do krajów rozwijających się, w których tempo wzrostu wydajności zostało znacząco spowolnione, a ich udział w światowym spożyciu uzależniony był od ceny pracy. W miejsce delokalizujących się dojrzałych przemysłów, zgodnie z rozwojem przemysłowym, powstawały nowe przemysły rejestrujące bardzo duże zwiększenie wydajności. W sumie od lat siedemdziesiątych w Stanach Zjednoczonych, Wielkiej Brytanii i Niemczech zaczęła jeszcze szybciej rosnąć wydajność w przemyśle, a wraz z nią zaczął spadać udział przemysłu w zatrudnieniu ogółem, gdyż zapotrzebowanie na jego produkty w krajach najbardziej rozwiniętych było już mocno nasycone.

Długookresowe przesunięcia w zatrudnieniu z przemysłu do usług, trwające od wczesnych lat siedemdziesiątych XX wieku (dezindustrializacja), odzwierciedlają głównie wpływ zróżnicowań we wzroście stóp produktywności między przetwórstwem a usługami. Jeśli bowiem realna wielkość produktu przemysłu przetwórczego nie ma w dłuższym okresie tendencji do szybszego wzrostu niż realna wielkość produktu usług, 
a produktywność $\mathrm{w}$ przetwórstwie, wywołana szybkimi zmianami w technologiach produkcyjnych, wzrasta niewspółmiernie szybciej niż w usługach, wówczas zatrudnienie będzie się przesuwało z przetwórstwa przemysłowego do usług. Sektor usług będzie musiał wchłonąć większą część całkowitego zatrudnienia, aby utrzymać realną wielkość produkcji na równi z poziomem realnej wielkości produkcji przemysłowej.

W pewnego rodzaju działalnościach (technologicznie progresywnych) tempo zwiększania produktywności jest szybsze niż w innych (technologicznie stagnacyjnych) ${ }^{3}$. Przetwórstwo przemysłowe jest - generalnie - technologicznie progresywne, dlatego jego znaczenie dla gospodarki wydaje się najważniejsze. Taka charakterystyka przetwórstwa przemysłowego wiąże się z jego wewnętrznymi atrybutami, takimi jak: łatwość standaryzacji, możliwość formalizowania informacji niezbędnych do produkcji w pakiety łatwo powtarzalnych informacji. Usługi natomiast znacząco różnią się w tym względzie od manufaktur. Na przykład usługi nieosobowe (impersonal), takie jak telekomunikacja, mają cechy podobne do przemysłu i mogą być kwalifikowane jako „technologicznie progresywne". Usługi osobowe (nierynkowe), jak np. opieka medyczna, trudno jest standaryzować, nie podlegają metodom produkcji masowej, stąd nazywane są technologicznie stagnacyjnymi (Baumol, Blackman, Wolff, 1989). Rozwój światowego rynku i technologii nadaje coraz większej dynamiki tym cechom usług, które wcześniej zamykały je w granicach rynków wewnętrznych. Zwiększanie zdolności handlowej usług umacnia dodatkowo rolę tego sektora w ścieżce rozwoju gospodarczego krajów (więcej: Kłosiński, 2011: 213-215).

W literaturze przedmiotu przyjmuje się na poziomie teoretycznym, że wzrost produktywności w przemyśle będzie najprawdopodobniej mniej ważny niż był wcześniej dla wzrostu ogólnej produktywności i standardów życia w zaawansowanych gospodarkach, ze względu na ustabilizowane spożycie jego produktów (nasycenie się popytu). Jednak w gospodarkach rozwijających się będzie on stanowił główny motor wzrostu gospodarczego, ze względu na silnie działający postęp techniczny, rosnące spożycie produktów i nasilającą się globalizację.

W miarę trwania procesu dezindustrializacji wzrost produktywności w gospodarce będzie coraz bardziej zależał od jej wzrostu nie tyle w przemyśle, co w sektorze usług. A na wzrost produktywności w usługach będzie wpływać przyszły rozwój w takich obszarach, jak technologie informacyjne czy zmiany w strukturach konkurencyjnych (Rowthorn, Ramaswamy, 1997: 22; Dasgupta, Singh, 2006). Jednak w opinii N. Kaldora stopa wzrostu produktywności w całej gospodarce zależy od ekspansji sektora przemysłowego, która nie tylko prowadzi do szybszego wzrostu produktywności w przemyśle, ale wywołuje efekt rozproszenia na całą gospodarkę (działanie prawa Verdoorna ${ }^{4}$ ). W warunkach liberalizacji handlowej i globalizacji przepływów towarowych w gospodarkach krajów wysoko rozwiniętych, mimo nasycenia się popytu na artykuły przemysłowe, sektor przetwórstwa przemysłowego (i stopa osiąganych w nim wzrostów produktywności) dalej jest najważniejszy dla wzrostu PKB per capita oraz ogólnej produktywności gospodarki, jak uważał Kaldor.

\footnotetext{
${ }^{3}$ Technologicznie progresywne i stagnacyjne odnoszą się do kategorii relatywnych - np. technologiczna stagnacja nie musi oznaczać niewielkiego wzrostu produktywności w kategoriach absolutnych.

${ }^{4}$ Szybszy wzrost produkcji podnosi produktywność na skutek działania rosnących efektów skali.
} 
W latach dziewięćdziesiątych XX i na początku XXI wieku w zatrudnieniu ogółem w usługach rynkowych (w tym przede wszystkim w usługach bankowych) nastąpił wzrost - w Wielkiej Brytanii o ok. 10\%, w Niemczech o prawie 6\%, a w zatrudnieniu ogółem w sektorze przemysłu przetwórczego nastąpił spadek - od ok. 7\% w USA i $10 \%$ w Niemczech do prawie 12,7\% w Wielkiej Brytanii. Kryzys z lat 2007-2008 wymusił na tych gospodarkach wsparcie dla polityki przemysłowej i zatrzymanie w zatrudnieniu ogółem spadku udziałów przetwórstwa przemysłowego. Uchroniło to je od gwałtownego spadku tempa wzrostu PKB per capita. Utrzymany w ten sposób, choć bardzo spowolniony wzrost PKB per capita, pozwolił - przy załamaniu się światowego popytu i wzroście bezrobocia w tych krajach - zwiększyć udział usług nierynkowych w zatrudnieniu ogółem, np. w USA dzięki zwiększonym wydatkom rządu na służbę zdrowia i edukację.

Do zbadania siły zależności między udziałami zatrudnienia w przetwórstwie przemysłowym oraz usługach rynkowych a PKB per capita w gospodarkach wybranych krajów posłużono się współczynnikiem korelacji. Aby zorientować się, jaka jest siła możliwego wpływu, określono również współczynniki determinacji (tab. 2).

Tab. 2. Siła zależności między udziałem zatrudnienia w przetwórstwie przemysłowym i usługach rynkowych a PKB per capita w wybranych krajach, w latach 2005-2014

\begin{tabular}{|c|c|c|c|c|}
\hline Relacje & Polska & Niemcy & $\begin{array}{c}\text { Wielka } \\
\text { Brytania }\end{array}$ & $\begin{array}{c}\text { Stany } \\
\text { Zjednoczone }\end{array}$ \\
\hline $\begin{array}{l}\text { Współczynniki korelacji udziału zatrudnienia } \\
\text { przemysłu przetwórczego w zatrudnieniu } \\
\text { ogółem i PKB wg PSN per capita w cenach } \\
\text { bieżących, w dol. międzynarodowych } \\
\text { (współczynnik determinacji) }\end{array}$ & $\begin{array}{r}-0,774 \\
(0,6)\end{array}$ & $\begin{array}{r}-0,852 \\
(0,7)\end{array}$ & $\begin{array}{r}-0,378 \\
(0,14)\end{array}$ & $\begin{array}{r}-0,593 \\
(0,35)\end{array}$ \\
\hline $\begin{array}{l}\text { Współczynniki korelacji udziału zatrudnienia } \\
\text { w usługach rynkowych w zatrudnieniu ogółem } \\
\text { i PKB wg PSN per capita w cenach bieżących, } \\
\text { w dol. międzynarodowych } \\
\text { (współczynnik determinacji) }\end{array}$ & $\begin{array}{r}0,914 \\
(0,8)\end{array}$ & $\begin{array}{r}0,813 \\
(0,66)\end{array}$ & $\begin{array}{r}0,019 \\
(0,0003)\end{array}$ & $\begin{array}{l}0,911^{*} \\
\left(0,8^{* *}\right)\end{array}$ \\
\hline
\end{tabular}

* Obliczenia dla lat 2009-2014

** Obliczenia dla lat 2009-2014

Źródło: OECD (2016b), GUS (2016a)

Współczynniki korelacji wskazują na silne zależności ujemne między udziałem zatrudnienia w przetwórstwie przemysłowym a PKB per capita w Polsce i Niemczech. Zależność ta pozostaje ujemna, ale stosunkowo słaba dla Wielkiej Brytanii i Stanów Zjednoczonych. Przy tym współczynniki determinacji dla Polski i Niemiec pokazują, że udziały zatrudnienia w przemyśle przetwórczym - w odpowiednio ok. $60 \%$ i 70\% determinują PKB per capita. Inaczej jest w przypadku Wielkiej Brytanii i Stanów Zjednoczonych, gdzie udziały zatrudnienia w przetwórstwie przemysłowym nie wydają się ważne w kształtowaniu poziomu PKB per capita. Zatrudnienie w przetwórstwie przemysłowym jest tam stabilne - na poziomie ok. $10 \%$ - i nie wchodzi w silną relację z PKB per capita. 
W Wielkiej Brytanii i Stanach Zjednoczonych - krajach, w których najwcześniej rozpoczęły się procesy dezindustrializacyjne, przemysł odgrywa obecnie mniejszą rolę niż np. w Niemczech. W Wielkiej Brytanii firmy przemysłowe (firmy-matki) mają tylko swoje siedziby, do których odprowadzane są zyski, tworzące PKB per capita tego kraju. Realna produkcja w Wielkiej Brytanii, podobnie jak w Stanach Zjednoczonych, bazująca na pracy (produkcja, w której postęp techniczny już nie działa), była już z końcem lat siedemdziesiątych XX wieku przenoszona do innych krajów. Natomiast w Niemczech procesy delokalizacji zaczęły występować dopiero w latach dziewięćdziesiątych.

W Wielkiej Brytanii jeszcze słabsza, ale dodatnia, jest relacja udziału zatrudnienia w usługach rynkowych i poziomu PKB per capita. Może być to skutkiem bardzo nasyconego rynku wewnętrznego, ograniczonymi zdolnościami handlowymi usług czy ich związkiem z obsługą realnej produkcji w przemyśle, która spadała w latach 2008-2009 i 2012-2013 (GUS, 2016c).

W pozostałych badanych krajach, oprócz Wielkiej Brytanii, udziały zatrudnienia w usługach rynkowych pozostają w silnym związku z PKB per capita i znacząco określają jego poziom. W Niemczech wynika to z wysokiego poziomu PKB osiąganego w tej gospodarce, co pozwala zwiększać realną produkcję w usługach rynkowych - w dużej mierze dzięki wzrostom zatrudnienia oraz podnoszeniu cen usług, którego nie hamują niskie dochody ludności.

W Polsce relacje udziału usług rynkowych w zatrudnieniu i poziomu PKB per capita są bardzo silnie dodatnie. Powodem tego są wzrosty wydajności w przemyśle wyprzedzające wzrosty wydajności w usługach. Do obsługi coraz większej produkcji przemysłowej sektor usług rynkowych potrzebuje większego zatrudnienia. Wzrost realnej produkcji usług osiągany poprzez wzrost zatrudnienia musi powodować wzrost cen. Stąd nieodzowny jest odpowiednio wysoki poziom PKB per capita.

Zarówno w Niemczech, jak i w Polsce zatrudnienie w usługach rynkowych i PKB per capita silnie na siebie oddziałują. W Polsce jednak poziom PKB per capita nie pozwala na zwyżkę cen usług rynkowych, a w związku z tym na większe tempo wzrostu zatrudnienia w tym sektorze, tj. absorpcję siły roboczej wypychanej z pozostałych sektorów (w Niemczech w rolnictwie pozostało jedynie niecałe 1,5\% zatrudnienia, natomiast w Polsce - blisko 10\% siły roboczej).

\section{WNIOSKI DLA POLSKI}

Możliwe jest, aby gospodarka przechodziła dezindustrializację w kategoriach zatrudnienia i produkcji, a popyt na artykuły przemysłowe był nadal rosnący i daleki od nasycenia. Dualizm tego procesu jest możliwy przy spotykanym bardzo często w krajach rozwijających się zjawisku bezzatrudnieniowego wzrostu gospodarczego. Dezindustrializacja może wtedy budzić niepokój, jeżeli jej symptomy pojawiają się w wielu rozwijających się krajach o niskim poziomie PKB per capita. Dezindustrializacja w kategoriach produkcji i zatrudnienia często oznacza nadmiar siły roboczej w rolnictwie, który albo pozostaje uwięziony w tym sektorze, albo zostanie przesunięty do niskoproduktywnych przemysłów i usług w strefie nieformalnej (Dasgupta, Singh, 2006: 5-6). 
Jedynym na razie możliwym do przyjęcia wyjaśnieniem nadmiernego udziału w zatrudnieniu ogółem sektora rolniczego w Polsce, średnio w badanym okresie na poziomie 15\% (jak wskazują dane z tab. 1), jest dualizm procesu dezindustrializacji, objawiający się przedwczesną, zachodzącą na stosunkowo niskim poziomie PKB per capita dezindustrializacją gospodarki. Udział przetwórstwa przemysłowego w zatrudnieniu ogółem w latach 1995-2014 kształtował się W Polsce prawie na niezmienionym poziomie ok. 20\% (tab. 1), przy ponad 100\% wzrostu jego wartości dodanej w ostatnich pięciu latach, liczonych w cenach stałych z 2000 roku (GUS, 2016b). W całym badanym okresie mieliśmy do czynienia w polskiej gospodarce $\mathrm{z}$ bezzatrudnieniowym rozwojem przemysłu w sektorze formalnym. Jeżeli przy dużym i dynamicznie rosnącym spożyciu dóbr przemysłowych produkcja rośnie jedynie w wyniku wzrostu wydajności, a zatrudnienie spada, będzie dochodziło do niekorzystnych zmian - wypierania siły roboczej z przemysłu (dezindustrializacja przy bardzo małym PKB per capita) oraz braku możliwości jej całkowitej absorpcji przez usługi.

Dochód per capita w polskiej gospodarce, zamiast dynamicznie wzrastać na skutek wzrostu zatrudnienia w przemyśle, kiedy wielkość spożycia dóbr przemysłowych rosła szybciej niż wielkość produkcji, rósł o wiele wolniej z powodu bezzatrudnieniowego wzrostu produkcji przemysłowej, chociaż w wyniku błędnych porównań jego tempo wydaje się być niekiedy imponujące. Natomiast zbyt mały poziom dochodów per capita powoduje, że wzrost spożycia usług nie jest na tyle duży, by popyt na pracę mógł zaabsorbować całą siłę roboczą wypychaną z przemysłu i uwięzioną w rolnictwie. Zmiany w okresie transformacji ustrojowej, jakie dokonały się w przetwórstwie przemysłowym w Polsce, są pokłosiem licznych zaniechań w obszarze polityki przemysłowej czy wręcz działań nakierowanych na „patologiczną formę dezindustrializacji” (Karpiński, Paradysz, Soroka, Żółtkowski, 2015: 33).

Jako jedną ze ścieżek stabilnego przyspieszenia wzrostu gospodarczego w Polsce podaje się odbudowanie potencjału przemysłowego naszej gospodarki (reindustrializację). Proces ten miałby polegać zwłaszcza na silnej koncentracji na zahamowaniu spadku zatrudnienia w przemyśle, okresowym jego wzroście, aż do ujawnienia się efektów automatyzacji w tym sektorze. Ważnym skutkiem tych zjawisk miałoby być „zwiększenie efektów innowacyjnych”. Największe szanse pojawienia się tych efektów upatruje się w przemyśle ekologicznym, przemyśle elektroniki nowej generacji, nanotechnologii, chemii specjalizowanej i biotechnologii, przemyśle lotniczym, kosmicznym i zbrojeniowym oraz w tradycyjnym przemyśle przetwórstwa surowców rolnych (Karpiński, Paradysz, Soroka, Żółtkowski, 2015: 314, 325).

\section{Podsumowanie}

Nadmierny wzrost udziałów usług finansowych w wartości dodanej gospodarek, generowany ich nominalnym zyskiem w latach dziewięćdziesiątych XX wieku, oraz kryzys popytowy, zapoczątkowany załamaniem się rynków finansowych w latach 2007-2008, uaktualniają aplikacyjność poglądów Kaldora o roli ekspansji przemysłu przetwórczego, ponieważ prowadzi ona do wzrostu średniej produktywności w całej gospodarce. Zwiększenie udziałów przemysłu w strukturze gospodarki prowadzi nie 
tylko do szybszego wzrostu realnej produktywności w samym przemyśle, ale również wywołuje efekt jej rozproszenia na realną sferę w całej gospodarce. W krajach rozwijających się przetwórstwo przemysłowe potencjalnie najszybciej absorbuje zasoby słabo wykwalifikowanej siły roboczej. Jak pokazało doświadczenie ostatniego kryzysu, sektor przemysłowy nadal pozostaje najważniejszym gwarantem trwałego wzrostu gospodarczego dla każdej gospodarki i wydaje się być to kwestią ponadustrojową. Analizy ekonomiczne dowodzą, że tylko przy odpowiednio wysokim poziomie PKB per capita sektor usług jest w stanie wchłonąc całą siłę roboczą wypychaną przez nowe technologie z rolnictwa i przemysłu. Powstający system będzie bowiem prowadził do niemal „nieograniczonych możliwości produkcyjnych” i do wypierania siły roboczej (Rifkin, 2001: 112).

W niektórych analizach możliwych skutków tych zmian rodzi to konieczność przeformułowania umowy społecznej w odniesieniu do zatrudnienia i stworzenia warunków uczestniczenia w życiu społecznym z dala od rynku (Rifkin, 2001: 299-301). Nowej istoty nadaje zmianom strukturalnym wizja silnego efektu mnożnikowego, wypływająca z „synergii pomiędzy filarami rewolucji przemysłowej”, która ma się opierać na odnawialnych źródłach energii i internecie jako obszarach wzrostu (Rifkin, 2011). Mimo pesymizmu Rifkina z połowy lat dziewięćdziesiątych XX wieku (Rifkin, 2001), dążenie do tego, aby zoperacjonalizować nową konstrukcję energetyczno-komunikacyjną gospodarek zaprezentowaną przez niego w drugiej dekadzie XXI wieku, dość jednoznacznie wskazuje na nadzieję, wciąż pokładaną w reindustrializacji gospodarek.

\section{Literatura \\ References}

Baumol, W.J., Blackman E.N., Wolff E.N. (1989). Productivity and American Leadership: the long view. Massachusetts, Cambridge: MIT Press.

Clark, C. (1957). The Conditions of Economic Progress. London: Macmillan.

Dasgupta, S., Singh, A. (2005). Will services be the new engine of economic growth in India? Centre for Business Research. University of Cambridge Working Paper, 310.

Dasgupta, S., Singh, A. (2006). Manufacturing, Services and Premature Deindustrialization in Developing Countries. A Kaldorian Analysis. UNU-WIDER WIDER Research Paper, 49.

Fisher, A.G.B. (1945). Economic Progress and Social Security. London.

Fisher, A.G.B. (1952). A note on tertiary production. The Economic Journal, 62.

Fourastié, J. (1954). Die Grosse Hoffnung des zwanzigsten Jahrhunderts. Köln-Deutz: Bund-Verlag. Fourastié, J. (1972). Myśli przewodnie. Warszawa: PIW.

GUS (2016a, 3 lipca). Rachunki narodowe. Pozyskano z http://stat.gov.pl/statystyka-miedzynarodowa/porownania-miedzynarodowe/tablice-o-krajach-wedlug-tematow/rachunki-narodowe/

GUS (2016b, 3 lipca). Roczne wskaźniki makroekonomiczne, wartość dodana brutto ogółem w cenach stałych z 2000 roku. Pozyskano z http://stat.gov.pl/wskazniki-makroekonomiczne/

GUS (2016c, 1 lipca). Tablice o krajach - przemysł i budownictwo. Pozyskano z http://stat.gov. $\mathrm{pl} /$ statystyka-miedzynarodowa/porownania-miedzynarodowe/tablice-o-krajach-wedlugtematow/przemysl-i-budownictwo/

Kaldor, N. (1967). Strategic Factors in Economic Development. New York State School of Industrial and Labour Relations. Ithaca NY: Cornell University. 
Karpiński, A., Paradysz, S., Soroka, P., Żółtkowski, W. (2015). Od uprzemysłowienia w PRL do deindustrializacji kraju. Warszawa: Wydawnictwo Muza SA.

Kłosiński, K.A. (2011). Światowy rynek usług w poczatkach XXI wieku. Warszawa: Polskie Wydawnictwo Ekonomiczne.

Kwiatkowski, E. (1980). Teoria trzech sektorów. Warszawa: PWN.

OECD (2016a). Stat Labour Force Statistics. DOI :10.1787/lfs-lfs-data-en

OECD (2016b, 3 lipca). Pozyskano z http://stats.oecd.org/viewhtml.aspx?datasetcode=SNA_ TABLE3\&lang=en\#

Piketty, T. (2015). Kapitał XXI wieku. Warszawa: Wydawnictwo Krytyki Politycznej.

Rifkin, J. (2001). Koniec pracy. Schyłek siły roboczej na świecie i początek ery postrynkowej. Wrocław: Wydawnictwo Dolnośląskie.

Rifkin, J. (2011). Trzecia rewolucja przemysłowa. Katowice: Wydawnictwo Sonia Draga.

Rodrik, D. (2016). Premature deindustrialization. Journal of Economic Growth, 21.

Rowthorn, R., Ramaswamy, R. (1997). Deindustrialization: causes and implications. IMF Working Paper, 42.

Waląg P. (2012). Determinanty zmian struktury zatrudnienia w okresie transformacji gospodarki polskiej. Uniwersytet Opolski, Wydział Ekonomiczny (niepublikowana praca doktorska).

Renata Śliwa, dr, Uniwersytet Pedagogiczny w Krakowie, Wydział Humanistyczny, Instytut Politologii. Obszar zainteresowań badawczych: transformacja gospodarcza Polski, przemiany strukturalne gospodarki Polski, ordoliberalizm, regulacja sektora infrastrukturalnego na przykładzie telekomunikacji w Polsce, innowacyjność gospodarki, efektywność procesów gospodarowania, bodźce w procesach gospodarowania.

Renata Śliwa, Ph.D., Pedagogical University of Cracow, Faculty of Humanities, Institute of Political Science. The author's research interests focus mainly on: economic transformation of Poland, structural change in Polish economy, ordoliberalism, regulation of infrastructure sector - telecommunication, innovativeness of the economy of Poland, effectiveness of economic processes, incentives in economic processes.

\section{Adres/address:}

Uniwersytet Pedagogiczny w Krakowie

Wydział Humanistyczny

Instytut Politologii

ul. Podchorążych 2, 30-084 Kraków, Polska

e-mail: renatasliwa@gmail.com

Piotr Waląg, dr, Uniwersytet Rolniczy w Krakowie, Wydział Inżynierii Produkcji i Energetyki, Instytut Inżynierii Rolniczej i Informatyki. Zainteresowania badawcze: teorie ekonomiczne dotyczące przemian strukturalnych, procesy zachodzące na rynku pracy w okresie transformacji gospodarki Polski, idee społecznej gospodarki rynkowej, struktura zatrudnienia, struktura produkcji, transformacja gospodarki, dualizm procesów dezindustrializacji, restrukturyzacja przemysłu, kryterium wyodrębnienia sektorów gospodarki, heterogeniczność sektora usług.

Piotr Waląg, Ph.D., University of Agriculture in Krakow, Faculty of Production and Power Engineering, Institute of Agricultural Engineering and Informatics. The author's research interests focus mainly on: theories of structural changes in market economy, labour market in the economic transformation in Poland, social market economy ideas, employment structure, production structure, economic transformation of Poland, restructuring the manufacturing industry, dualism of deindustrialization, criteria of economy division, heterogeneity of service sector.

Sylwester Tabor, dr hab., inż., Uniwersytet Rolniczy w Krakowie, Wydział Inżynierii Produkcji i Energetyki, Instytut Inżynierii Rolniczej i Informatyki. Zainteresowania badawcze: ekonomika mechanizacji rolnictwa, organizacja i zarządzanie w inżynierii rolniczej, postęp techniczny, modernizacja wyposażenia technicznego 
i związanej z nim zmiany procesów technologicznych, analiza procesów technologicznych produkcji roślinnej, efektywność postępu naukowo-technicznego, sektor rolnictwa.

Sylwester Tabor, Ph.D., University of Agriculture in Krakow, Faculty of Production and Power Engineering, Institute of Agricultural Engineering and Informatics. The author's research interests focus mainly on: economics of agriculture engineering, organization and management in agriculture engineering, technological improvements and its consequences, analysis of technological processes in plant-based production, effectiveness of scientific and technological advancement, agriculture sector

\section{Adres/address:}

Uniwersytet Rolniczy w Krakowie

Wydział Inżynierii Produkcji i Energetyki

Instytut Inżynierii Rolniczej i Informatyki

ul. Balicka 116B, 30-149 Kraków, Polska

e-mail: piotrwalag@gmail.com (Piotr Waląg)

e-mail: Sylwester.Tabor@ur.krakow.pl (Sylwester Tabor) 